\title{
Research on Innovation Teaching of Physical Education in College
}

\author{
Shang Haiwei ${ }^{1, a}$ \\ ${ }^{1}$ Qingdao Huanghai University \\ Qingdao, China \\ a707848150@qq.com
}

\begin{abstract}
Innovation teaching in physical education means cultivating students' innovative consciousness, ability and spirit, training their creative thinking, digging their creative potential and improving the ability of their creative learning. Main problems and corresponding countermeasures of traditional physical education are analyzed and studied in this paper. It can be known that sports activities need to cultivate students' innovative personality and develop their creative intelligence in college education. In order to truly reflect the application of innovative education in modern sports classroom teaching, it is necessary for PE teachers to have a certain creative ability, so as to cultivate outstanding creative talents. Sports education should give full play to the main role of students in the process of education, make students change from passive learning to active knowledge, turn teaching activities into active students' thinking, enlighten students' thinking and guide students' innovation.
\end{abstract}

Keywords-Physical education; Innovation; Sports; Teaching method

\section{INTRODUCTION}

College students are in the most active period of creative thinking. It is very favorable for college students to carry out innovative education [1]. Therefore, in the course of physical education, physical education teachers need to pay attention to the cultivation of students' innovative ability, which is also the responsibility and obligation of the general physical education teachers in the new period of education [2]. In the course of physical education, physical education teachers should try to inspire students with inspiring language to maximize the enthusiasm and initiative of students' thinking and to invest in the best way. In view of this, it is necessary to carry out innovative research on traditional physical education.

\section{STIMULATE THE CREATIVE THINKING OF SPORTS DEVELOPMENT}

Physical education teachers need to cultivate students' innovative thinking in sports learning, arouse students' initiative in learning and pay attention to the flexibility of methods. If teaching always starts from the premise of determination, it will cause the straightness of students' thinking, which is not conducive to the cultivation of the independence and creativity of students' thinking, which hinders the optimization of students' thinking quality [3]. In teaching, teachers should speak as little as possible, keep the teaching content of the right to use certain value of thinking, promote the development of students' thinking ability, and master the methods of innovation.

\section{A. Activity innovation}

Teachers teach students basic skills, and students choose combinations according to their own level. Such as rope skipping, ring tracking, pat, jump and catch pigs. The activity should be constantly updated and innovated in the content of teaching materials, so as to stimulate students' interest in learning. At the same time, teachers should be conscientious, find positive and positive guidance, and transform their free innovation into intentional innovation. It not only fully exercises the body of students, but also creates the creative ability of students and develops the ability to do things. In the interest of sports, students feel boundless joy and participate actively, which is conducive to the completion of teaching objectives, and is conducive to the development of students' personality and cultivation of beauty. In the traditional teaching of physical education, teachers often choose some competitive sports to teach in the course of teaching, and the final evaluation is also the standard of taking part in these projects to assess the students' achievements. They often result in those who are born with better physical quality and some top athletes. They get good grades or even exceed the highest standards. Under the new curriculum standard implementation, as a physical education teacher, we must change our concept.

\section{B. Setting up the concept of innovation in sports}

Teachers should encourage and guide students to take part in physical exercise through some effective means to improve their physical quality and physical fitness in two aspects, so that they are less ill or not sick, which is one of the important goals of the sports class. For a long time, the purpose of school physical education is to strengthen the physical fitness of the students to make the body healthier, and the limited two sports classes per week are often unable to meet the purpose of strengthening physical fitness and improving health. Health is a long-term process of persistence, that is, a gradual process, it is not possible to achieve good results in a short time, because the changes in human body function are regular [4]. Due to the heavy learning tasks of students nowadays, they are not only a competition of intelligence, but also a contest of physical strength. Without a healthy body, it will be very difficult to persist until the final victory. Therefore, in sports teaching, we should focus on how to stimulate and arouse students' interest and enthusiasm in physical exercise through some teaching methods. Gradually develop their hobbies and consciously participate in the habit of physical exercise, so that they can enjoy the fun in sports. Slowly let sports become an 
indispensable part of their lives, accompanied by their whole life.

\section{The promotion of rational knowledge}

As we all know, teachers' demonstration is an effective way for students to learn new knowledge and new skills. If the teaching method is monotonous and boring, the students are affected by their own knowledge system, it is difficult to learn, understand and accept the knowledge accurately, and it will give students a strange feeling. Due to the restriction of teaching time, students cannot review in class, so that they can only have a smattering of knowledge. For a long time, students often form erroneous formulary.

Physical education teachers should teach students to use rational methods to learn. Then, in the process of learning new knowledge and new skills, students will draw inferences from others. In this way, we not only follow the students' cognitive law, fully embody the subjectivity of students, but also embody the teaching idea of teacher dominant and improve the effect of practice [5].

\section{PAY ATTENTION TO THE FEEDBACK OF PHYSICAL EDUCATION COURSE}

Physical education is not only a teaching process, but also a process of interaction between teaching and learning. Blindly instilling sports knowledge into students is just the level of a teacher. Only by constantly learning in education and innovating the teaching on the basis of the actual situation of students can we gradually improve the teaching level. Physical teachers should selflessly impart knowledge to their students, protect their students and care for them, and set an example for their noble behavior. In the face of the backward students, they should not use violence or corporal punishment, but should use double love to help them improve. This is not only from the professional angle, but also from the legal point of view of the teachers' obligations.

\section{A. Professional quality}

Physical education teachers should have excellent professional quality. The training of these professional qualities requires teachers to stand in the angle of teaching objects, to develop the spirit of love and dedication, to make the students feel good with good intentions, and to make the teaching of physical education lively. The result of PE classroom teaching is directly related to the design of classroom teaching ability. Scientific and reasonable classroom design is conducive to the normal development of physical education. The design of physical education classroom requires students as the core, activity as the medium and emotion as the link, so that the teacher-student bilateral teaching relationship will develop harmoniously. As teachers, we should anticipate factors that may arise in classroom teaching, especially from students.

\section{B. Cultivating students' innovative consciousness}

Through the external training and internal transformation of teachers, students should stimulate creative consciousness and creative potential, improve the development of personality in the process of practice interaction, and internalize the external things into the body and mind in order to complete the cultivation of students' creative ability in the teaching. In the traditional physical education, the students' main role is ignored, the students' rich imagination, the unique intellectual thinking and emotional activities are completely suppressed, the students are passively received, lost the initiative of learning, become the slaves of learning, which is the sorrow of traditional teaching, and also the teacher's loss of duty.

The new model, after injecting teachers' innovative spirit and innovative consciousness, can improve the initiative of students' learning, relieve the restraint of learning and activate the students' consciousness of innovation. The activation and cultivation of innovation consciousness need to give students a relaxed learning atmosphere and a democratic atmosphere conducive to the free play of students. Traditional education makes students unable to open their minds to "violate" teachers in class. Only by accepting passively and passively, can they not form their own independent thinking. Educational methods and teaching attitudes determine the learning effect of students to an absolute degree. Because the development of students' creative ability is a potential possibility, the teaching work of the teacher can promote the potential of the students to turn to the reality. At the same time, the personality characteristics and ways of the creative ability of the teachers themselves have a subtle influence on the students.

\section{THE IMPLEMENTATION OF PHYSICAL EDUCATION CURRICULUM INNOVATION}

\section{A. The significance of sports innovation}

Innovation is the soul of a nation's progress and an inexhaustible motive force for the prosperity of a country. The focus of the new curriculum reform is to cultivate students' innovative spirit and practical ability. As far as sports discipline is concerned, traditional physical education emphasizes simply letting students master "double bases". The result of this education can only produce a batch of "mechanical imitation" or "blind practice" labor force. The cultivation of innovation ability not only requires students to complete the "imitation" practice, but also requires students to produce new ideas in the course of practice so that students can give full play to their creative potential and stimulate their creative thinking [6]. Tolstoy said, "if students learn in school, they will never create anything themselves. Then their life will always be imitation and plagiarism." To some extent, the new curriculum reform is to fully allow students to accept the people as the society and contribute the greatest potential to the development of society, and pay attention to the formation of the spirit of the people, instead of taking the students as the acceptor of knowledge and skills. In this sense, without the cultivation of innovative ability, there can be no real curriculum reform. Therefore, cultivating students' innovative ability is the core of the new curriculum reform. 
The cultivation of students' innovative ability is not a matter of a single day. It needs a long-term process. No matter how the student's innovation describes it, no matter how much it sees it as an internal and regular activity result, it always has an attribute of uncertainty. The innovation process of different students is different, different and diverse.

\section{B. Implementation scheme}

Physical education is a very important aspect of school education. It has distinct and unique characteristics. Most of the sports activities are carried out in practical activities. It provides students with full opportunity to observe, think, operate and practice. It cannot be compared to other disciplines to promote students' innovative spirit and creative ability. The proposed advantage. Therefore, the PE teachers should jump out from the traditional sports education model circle, establish the core position of "innovation" in the physical education work in the educational theory and guiding ideology, and consciously bring out the innovative consciousness of the students and cultivate the students' innovative ability as the most important part of the new curriculum reform.

In the teaching process of gymnastics and rhythmic gymnastics, physical education is first from easy to difficult system mastering and reviewing the technical action of teaching syllabus; secondly, it can enrich all kinds of technical movements that are not arranged in the textbook but in line with the students' cognition law and simple and easy to learn. You can also focus on some simple knowledge of difficult movements and choreography. On this basis, we should give full play to the students' subjective and dynamic role, let them set up a complete set of actions by themselves, and let the combination of the characteristics of the students come out to demonstrate, the students are evaluated, the teachers are fully encouraged, and the suggestions for improvement are put forward. Such innovative thinking and innovative activities will undoubtedly promote the improvement of students' innovative consciousness and innovation ability.

\section{Increasing sports games}

Sports games are a special kind of classroom activities and exercise methods. Sports games are integrated activities, which are made up of certain plots, forms, rules and results. Students can explore their own ways or group discussions to win their opponents within a feasible range, which are full of fair competition and risk winning. At the same time, students can also create sports games by themselves or groups. Teachers and students can jointly evaluate which is better or worse. Once the students are highly motivated, they can effectively stimulate team spirit and cooperation spirit, which is conducive to the improvement of intelligence development and innovation ability.

\section{Expanding the physical education course}

The discovery method has good effect in physical education teaching. Its prominent feature is that it does not tell the students the ready-made answer, and lets the students use their own knowledge and experience, give full play to their subjective initiative, and explore ways to solve the problems, so that they can quickly master the technical movements and related knowledge, methods and principles.

In the course of physical education, it is necessary to introduce or create a specific scene with a certain emotional color and vivid image in the course of physical education, so as to cause the students to experience a certain attitude. Through various teaching means, the situation is displayed in life, the scene is demonstrated in kind, the situation is reproduced with pictures, video and multimedia, the situation is rendered with music, the situation is realized by the performance, and the situation is described in language. For example, all kinds of Sports Festival, single sports meeting, ball game, picnic, so as to stimulate the students' feelings, help students understand the physical education materials, promote the overall quality of students and improve the ability to innovate.

\section{THE DEVELOPMENT OF SPORTS INNOVATION ABILITY}

\section{A. Emphasizing the hierarchy of different students}

Because there are individual differences between people, teaching objectives should not be generalized. The teaching process should emphasize stratification, put forward different goals and requirements for different students, and adopt different teaching contents and methods. Specific strategies should be focused on counselling low level students, through repeated attempts, repeated practice, to solve doubts and difficulties, so that they can be on the next level. Let highlevel students develop creatively on the basis of consolidation and create other practice methods. This enables students of different levels to have the possibility of success and feel the joy of success, which is conducive to stimulating students' self-confidence.

\section{B. Advocating a purposeful attempt}

The essence of trying is practice. And the formation of innovation consciousness, the cultivation and improvement of creativity must be carried out through practice. Therefore, in teaching, students should be encouraged to try with purpose. Teachers should allow and encourage students to question teachers and reverse thinking in the process of teaching. Teachers should learn to listen and inspire students not to copy the teacher's methods to complete their actions. For those good ideas and practices to be promoted in a timely manner, even if they are wrong, do not accuse them more. Let students try to sum up their experiences through trial, questioning and practice, so that students can experience, think, find and find ways to solve problems in practice.

In the course of physical education, students should often organize students to watch sports competitions and video and television, and the conscious introduction or creation of specific scenes with a certain emotional color and vivid image 
can cause the students to experience a certain attitude. Through various teaching means, the situation is displayed in life, the scene is demonstrated in kind, the situation is reproduced with pictures, video and multimedia, the situation is rendered with music, the situation is realized by the performance, and the situation is described in language.

\section{Establishing a new relationship between teachers and students}

In the course of teaching, physical education teachers should fully mobilize the enthusiasm of students' activities, stimulate their active participation in the active desire and interest. In the organizational form of the class, they should be more active, according to the requirements and characteristics of the students, carry out a variety of forms of teaching, give the students full free activity, and make the students' personality open. In view of the non-intellectual factors affecting the innovation ability, the PE teachers should not only stimulate the students' enthusiasm for innovative learning, but also cultivate the personality characteristics that are helpful to the innovation.

\section{CONCLUSION}

The basic means of physical education are physical exercises, which are characterized by strong practicality, great openness and frequent mobilization, and students' mastery of knowledge and skills of sports must be realized through their own activities. Teachers should create various opportunities, give full play to the strength of the collective and excavate the creative potential of students. Creative education in physical education is based on the cultivation of people's innovative spirit and practical ability as the basic value orientation and the cultivation of creative talents as the main goal. Its proposal is not only the need to carry forward the innovative nature of human beings, but also the inevitable requirement of deepening education reform and promoting quality-oriented education in an all-round way. It reflects the call of innovative talents in the era of knowledge economy.

\section{REFERENCES}

[1] Ping S. "On school physical education and innovative education". Sichuan Sports Science, 2012, pp.40-44.

[2] Lifeng L. "Several suggestions on the curriculum of innovative education in physical education". Journal of Shenyang Sport University, 2012, pp.82-90.

[3] Deng R X. "Physical education theory framework for physical exercise experience". Sports Journal, 2007, pp.112-122.

[4] Wang B. "Current situation and Countermeasures of physical education in Senior High Schools under the new curriculum". Education, 2016, pp.215-218.

[5] Wati H. "Research on college physical education teaching mode," Sports Science, 2011,pp.79-104.

[6] Jiankun L. "Analysis of sports innovative education' physical quality". Sichuan sports science, 2006, pp.399-415. 